\title{
Desorption of tetracycline from montmorillonite by aluminum, calcium, and sodium: an indication of intercalation stability
}

\author{
P.-H. Chang $\cdot$ Z. Li $\cdot$ J.-S. Jean $\cdot$ W.-T. Jiang • \\ Q. Wu C C.-Y. Kuo $\cdot$ J. Kraus
}

Received: 13 October 2012/Accepted: 23 February 2013/Published online: 29 March 2013

(C) Islamic Azad University (IAU) 2013

\begin{abstract}
As the uptake of cationic drugs, such as tetracycline (TC), was attributed to cation exchange, the stability of adsorbed TC on a Ca-montmorillonite SAz-2 was studied using cationic solutions of different valence charges under different $\mathrm{pH}$ conditions. At the initial loading of $356 \mathrm{mg} \mathrm{g}^{-1}$, the amounts of TC desorbed by $0.05 \mathrm{M}$ $\mathrm{AlCl}_{3}, \mathrm{CaCl}_{2}$, and $\mathrm{NaCl}$ were $133 \pm 4,83 \pm 6$, and $50 \pm 4 \mathrm{mg} \mathrm{g}^{-1}$, respectively, or 37,23 , and $14 \%$. However, when the amount or percentage of TC desorbed was normalized to the equivalence of each cation, the values were in the range of $44-50 \mathrm{mg} \mathrm{g}^{-1}$ or $11-14 \%$ per $10 \mathrm{mmol}$ of charge. The kinetics of TC desorption were moderately fast and almost reached equilibrium in $6 \mathrm{~h}$. The results followed the pseudo-second-order kinetic model with reaction rate in the order of $\mathrm{AlCl}_{3}>\mathrm{CaCl}_{2}>\mathrm{NaCl}$ at a higher initial TC loading level. The total amount of TC
\end{abstract}

Electronic supplementary material The online version of this article (doi:10.1007/s13762-013-0215-2) contains supplementary material, which is available to authorized users.

P.-H. Chang · Z. Li · J.-S. Jean $(\bowtie) \cdot$ W.-T. Jiang

Department of Earth Sciences, National Cheng Kung University, 1 University Road, Tainan 70101, Taiwan

e-mail: jiinshuh@mail.ncku.edu.tw

Z. $\mathrm{Li} \cdot \mathrm{Q} . \mathrm{Wu}$

Faculty of Earth Sciences, China University of Geosciences Wuhan, Hubei 430074, China

Z. Li · J. Kraus

Department of Geosciences, University of Wisconsin, Parkside, 900 Wood Road, Kenosha, WI 53144, USA

C.-Y. Kuo

Department of Public Health, College of Health Care and Management, Chung Shan Medical University, No. 110, Sec. 1, Chien-kuo N Road, Taichung 40242, Taiwan desorbed after five desorption cycles followed the order of $\mathrm{AlCl}_{3}>\mathrm{CaCl}_{2}>\mathrm{NaCl}$, too, suggesting that cations with higher positive charges, thus, less hydrated, are preferred to remove adsorbed cationic drugs. The FTIR analyses showed larger band shift when $\mathrm{Al}^{3+}$ was used as the desorbing reagent. The XRD patterns before and after TC desorption revealed no changes in basal spacing, even after five desorption cycles, suggesting that the removal of TC from SAz-2 was largely from the external surfaces.

Keywords Ca-montmorillonite - Cation exchange . Complexation - Desorption - Metal cations - Tetracycline

\section{Introduction}

Antibiotics are widely used to inhibit and kill human and animal disease pathogens, and to promote animal growth. Approximately, $70 \%$ of the 16 million kilogram of antimicrobial chemicals used each year in the United States consisted of antibiotics administered to livestock, not to fight infection but to promote animal growth (King 2006). In the European Union, 5 million kilogram of antibiotics was used for therapeutic purposes (Kay and Boxall 2000). In addition to the large quantity of antibiotics used, many antibiotics also have low metabolic rate in human bodies (10-40 \%) (Halling-Sørensen et al. 1998). Slow accumulation of antibiotic residues would impose a great threat to the environment. For example, up to $20 \mathrm{mg} \mathrm{L}^{-1}$ of tetracycline (TC) was detected in manure (Hamscher et al. 2002), and half of the 139 rivers surveyed in the United States had detection of antibiotics (Kolpin et al. 2002). In addition to environmental contamination, the presence of antibiotics in the environment would also increase bacterial resistances to antibiotics (Figueroa et al. 2004; Sarmah 
et al. 2006). Thus, the removal of antibiotics from soil and water, particularly from drinking water or groundwater, is becoming an emerging issue.

Differing from non-polar organic pollutants, many antibiotics are ionizable organic compounds. In general, they are hydrophilic. They may contain several ionic functional groups, having one or more dissociation constants (pKa), and may be cationic, zwitterionic, or anionic under different $\mathrm{pH}$ conditions. Thus, one of the most important factors affecting the speciation of antibiotic and antibiotic-solid interactions is the solution $\mathrm{pH}$.

Tetracycline is one of the most widely used antibiotics. It exists as a cation, +00 , when $\mathrm{pH}<3.3$; as a zwitterion, +-0 , when $3.3<\mathrm{pH}<7.7$; and as a monovalent anion, +-- or a divalent anion $0--$, when $\mathrm{pH}>7.7$. For TC, the $-\mathrm{OH}$ and $-\mathrm{CONH}$ functional groups could interact with negatively charged adsorption sites on soil surface by metal-bridging (Wessels et al. 1998; Mackay and Canterbury 2005). However, the positively charged $-\mathrm{NH}\left(\mathrm{CH}_{3}\right)_{2}$ functional group could interact with adsorption sites of negatively charged clay minerals through electrostatic interaction, or cation exchange with those previously attached to mineral surfaces (Figueroa et al. 2004). In addition, TC could adsorb to the surfaces of metal oxides via surface complexation of metal ions (Gu et al. 2007). TC contains multiple polar functional groups and could form hydrogen bonding with the polar part of soils ( $\mathrm{Gu}$ et al. 2007). The combination of different adsorption mechanisms enables TC adsorbing strongly on many solid surfaces with a higher capacity.

The presence of multivalent metal ions (such as $\mathrm{Ca}^{2+}$, $\mathrm{Mg}^{2+}, \mathrm{Cu}^{2+}, \mathrm{Al}^{3+}$, and $\mathrm{Fe}^{3+}$ ) is an important factor to control the adsorption behavior of some antibiotics. At high $\mathrm{pH}$, these cations can play a bridging role, connecting the negatively charged part of the antibiotic and the negative adsorption sites of solid surface by covalent bonds, to form complexes of antibiotics-metal ion-adsorption media, thus contributing to adsorption (Mackay and Canterbury 2005). Addition of $\mathrm{Ca}^{2+}$ or $\mathrm{Cu}^{2+}$ under alkaline condition would significantly promote the TC adsorption capacity on montmorillonite (Loke et al. 2002; Wang et al. 2008). Simultaneous adsorption and desorption of cadmium and tetracycline on cinnamon soil showed a concurrent increase in TC adsorption in the presence of $\mathrm{Cd}$ and the increase was attributed to bridging the TC and soil surface in the presence of Cd (Wan et al. 2010). On the other hand, the presence of $\mathrm{Cu}(\mathrm{II})$ in the soil solution suppressed the adsorption of $\mathrm{TC}$ on soils at $\mathrm{pH}$ less than 4.7, due to the competition of $\mathrm{Cu}^{2+}$ against TC, TC-Cu complexes in aqueous phase, and to the increased positive surface charge of soil by $\mathrm{Cu}$ (II) adsorption (Jia et al. 2008). Adsorption of TC on $\mathrm{Al}_{2} \mathrm{O}_{3}$ was involved in formation of complexes (Chen and Huang 2010). Meanwhile, coating of hydrous Al oxide (HAO) with soil humic acid significantly suppressed TC adsorption, attributable to altered HAO surface charge characteristics and/or direct competition between Elliott soil humic acid and TC for potential sorption sites ( $\mathrm{Gu}$ and Karthikeyan 2008).

The presence of soluble organic matter is another important factor to control antibiotic-solid interactions. Many functional groups, such as deprotonated - $\mathrm{COO}-$ in organic matter, offer the possibility of adsorption sites for antibiotics (Sibley and Pedersen 2008). Hydrogen bonding between antibiotics and the polar functional groups of organic matter could contribute further to antibiotic adsorption (Chen and Huang 2010). At low concentrations, co-adsorption of dissolved organic matter (DOM) could promote further adsorption of antibiotics on montmorillonite (Kulshrestha et al. 2004). On the contrary, the significant solubilization power of DOM, when present in high concentration, may facilitate removal of antibiotics from sorbent.

Although extensive studies were conducted to investigate the mechanisms of antibiotic adsorption on swelling clays, no systematic research was reported on desorption of TC from these clays. Even though antibiotics are tightly adsorbed by clay particles, they are still biologically active and may influence the selection of antibiotic resistant bacteria in the terrestrial environment (Chander et al. 2005). Thus, a systematic study on desorption behavior of adsorbed antibiotics would provide evidences whether the remained antimicrobial activity was actually due to significant desorption or not. In this study, the desorption of TC from a swelling clay SAz-2 was tested under different kinetic and $\mathrm{pH}$ conditions, and in the presence of different desorbing reagents to determine the relative stability of TC adsorbed on the surface and in the interlayer of swelling clays. This research was carried out in February-May, 2012 in the Hydrogeology Laboratory of the Earth Sciences Department, National Cheng Kung University, Tainan, Taiwan.

\section{Materials and methods}

\section{The sorbent}

The sorbent used was a Ca-montmorillonite SAz-2, a dioctahedral smectite, obtained from Clay Minerals Society. It was provided as a replacement for SAz-1. The sample received was in chunky form and was crushed to powders to be used in this study. However, further purification was not performed. It contained 95-100\% montmorillonite and $1-2 \%$ quartz with a chemical composition of $60.4 \% \mathrm{SiO}_{2}$, $17.6 \% \mathrm{Al}_{2} \mathrm{O}_{3}, 0.24 \% \mathrm{TiO}_{2}, 1.42 \% \mathrm{Fe}_{2} \mathrm{O}_{3}, 0.10 \% \mathrm{FeO}$, $0.08 \% \mathrm{MnO}, 6.46 \% \mathrm{MgO}, 2.82 \% \mathrm{CaO}, 0.06 \% \mathrm{Na}_{2} \mathrm{O}$, 
$0.19 \% \mathrm{~K}_{2} \mathrm{O}, 0.02 \% \mathrm{P}_{2} \mathrm{O}_{5}$, and $0.29 \% \mathrm{~F}$. The reported cation exchange capacity (CEC) and specific surface area of SAz-1 were $1.2 \mathrm{meq}^{-1}$ and $97 \mathrm{~m}^{2} \mathrm{~g}^{-1}$, respectively, with $\mathrm{Ca}$ as the major exchangeable cation.

\section{Chemicals}

The TC was obtained from Calbiochem (Darmstadt, Germany) and was used as received. It has a molecular weight of $444.44 \mathrm{~g} / \mathrm{mol}$ and a solubility of $1.7 \mathrm{~g} \mathrm{~L}^{-1}$. Like some other veterinary antibiotics, TC has multiple ionizable functional groups tricarbonylamide, phenolic diketone, and dimethylamine (Fig. 1). Its three acid dissociation constants were 3.3, 7.7, and 9.7, respectively (Sibley and Pedersen 2008), resulting in a cationic form at $\mathrm{pH}<3.3$, zwitterionic form at $\mathrm{pH} 3.3-7.7$, monovalent anionic form at $\mathrm{pH}$ 7.7-9.7, and divalent anionic form at $\mathrm{pH}>9.7$ (Fig. $\mathrm{S} 1$ in supporting information). It is extremely hydrophilic with a $\log \mathrm{K}_{\mathrm{ow}}$ value of -2.2 to -1.3 (Miller et al. 1977; Gu and Karthikeyan 2005), making it hardly having any adsorption on hydrophobic surfaces. The $\mathrm{Al}^{3+}, \mathrm{Ca}^{2+}$, and $\mathrm{Na}^{+}$were $\mathrm{AlCl}_{3}, \mathrm{CaCl}_{2}$, and $\mathrm{NaCl}$ obtained from Katayama Chemical (Osaka, Japan).

Ciprofloxacin hydrochloride (CIP) with purity higher than $99.6 \%$ was purchased from Hangzhou Minsheng Pharmaceutical Group Co. Ltd (China) and was used as one of the desorbing agents to investigate the influence of present organic cations on TC removal from montmorillonite. It has a molecular weight of $331 \mathrm{~g} \mathrm{~mol}^{-1}$, a solubility up to $3.3 \mathrm{~g} \mathrm{~L}^{-1}$, a $\log \mathrm{K}_{\mathrm{ow}}$ value of -1.51 to -1.13 , and two $\mathrm{pK}_{\mathrm{a}}$ values of 6.1 and 8.7, respectively (Montero et al. 1997; Zupancic et al. 2002).

\section{Batch experiments}

Adsorption experiments were first performed to determine the TC adsorption capacity on SAz-2 in comparison to

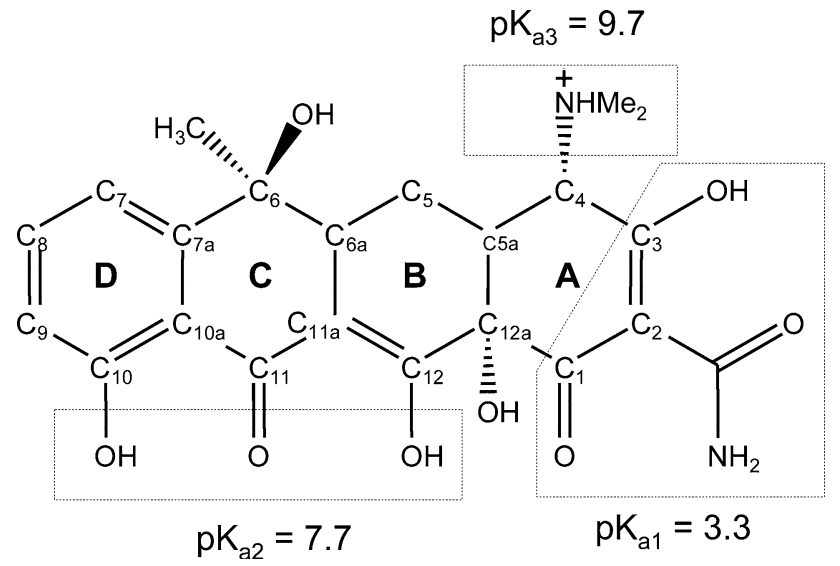

Fig. 1 Molecular structure of TC on a planar view
SAz-1. To each 50-mL centrifuge tube, $0.1 \mathrm{~g}$ of SAz-2 and $20 \mathrm{~mL}$ of TC solution with varying concentrations were combined and shaken for $24 \mathrm{~h}$. After being centrifuged, the supernatants were removed and analyzed for equilibrium TC concentration. The amount of TC adsorbed was determined by the difference between the initial and equilibrium solution concentrations. After the supernatants were decanted, $20 \mathrm{~mL}$ of desorbing solution at an initial concentration of $0.05 \mathrm{M}$ was added and the mixture shaken for varying amount of time for kinetic study, and at different $\mathrm{pH}$ conditions for $\mathrm{pH}$-dependent desorption. All tubes were wrapped with aluminum foils to prevent lightinduced decomposition.

For kinetic desorption studies, the initial TC loadings were 37,183 , and $356 \mathrm{mg} \mathrm{g}^{-1}$. As the solution was not buffered, the equilibrium solution $\mathrm{pH}$ varied from 3.5 to 4.6 under the desorption of $0.05 \mathrm{M} \mathrm{Al}^{3+}, \mathrm{Ca}^{2+}$, and $\mathrm{Na}^{+}$. In this $\mathrm{pH}$ range, the $\mathrm{TC}$ will be mainly in its zwitterionic form $\mathrm{TCH}_{2}^{0}$ (Fig. 1). The mixing time was $0.25,0.5,1.0$, $2.0,4.0,8.0$, and $24.0 \mathrm{~h}$. For $\mathrm{pH}$ desorption edge experiments, the initial TC loadings were 187 and $400 \mathrm{mg} \mathrm{g}^{-1}$, corresponding to 35 and $75 \%$ of the CEC of SAz-2. The equilibrium solution $\mathrm{pH}$ was adjusted by adding $\mathrm{HCl}$ or $\mathrm{NaOH}$ from 2 to 11 with an increment of approximately 1 . In addition, a five-cycle desorption experiment was also performed, each with a concentration of $0.05 \mathrm{M}$ of desorbing reagent. Distilled water was used as one of the desorbing reagents. The time for each desorption cycle was $6 \mathrm{~h}$. After equilibration, the mixtures were centrifuged at $10,000 \mathrm{rpm}$ for $2 \mathrm{~min}$, the supernatants passed through $0.45-\mu \mathrm{m}$ filters before being analyzed by an UV/Vis spectrophotometer. The amount of TC desorbed was calculated from the equilibrium TC concentrations taking the liquid-to-solid ratio $(20 \mathrm{~mL}-0.1 \mathrm{~g})$ into consideration.

Although the concentrations of TC used in this study were much higher than its expected environmental concentration, the goal of this study was mainly focused on investigating the TC desorption behavior, competitive effects in the presence of metal cations, and the stability of TC adsorbed on the surface or intercalated in the interlayer of SAz-2.

Methods of analyses

The equilibrium TC concentrations were analyzed by a UV/Vis Spectrophotometer (SmartSpec 3000, Bio-Rad Corp.) at a wavelength of $254 \mathrm{~nm}$. Calibration was made with five standards between 5 and $50 \mathrm{mg} \mathrm{L}^{-1}$ with an $r^{2}$ value no less than 0.99. Powder X-Ray diffraction (XRD) analyses were performed on a Rigaku D/Max-IIIa diffractometer with Ni-filtered $\mathrm{CuK} \alpha$ radiation at $30 \mathrm{kV}$ and $20 \mathrm{~mA}$. The samples were scanned in the range $2-10^{\circ}$ $2 \theta$ under continuous mode with a speed of $1^{\circ} 2 \theta \mathrm{min}^{-1}$. 
A $0.3-\mathrm{mm}$ receiving slit and $1^{\circ}$ divergent slit were used. FTIR analyses were performed on a Perkin Elmer Spectra One Spectrometer equipped with an attenuated total reflection (ATR) accessory. The spectra were obtained by accumulating 256 scans at a resolution of $4 \mathrm{~cm}^{-1}$.

\section{Results and discussion}

TC adsorption on SAz-2

Previous results showed that TC adsorption on SAz-1 reached a capacity of $462 \mathrm{mg} \mathrm{g}^{-1}$ and the TC adsorption can be well modeled by the Langmuir isotherm ( $\mathrm{Li}$ et al. 2010). As SAz-2 is a replacement for SAz-1, the first objective was to compare the TC adsorption behavior on SAz-2 in comparison to that on SAz-1. A typical TC adsorption isotherm was illustrated in Fig. 2. The TC adsorption data fitted to the Langmuir adsorption isotherm well with a TC adsorption capacity of $449 \pm 23 \mathrm{mg} \mathrm{g}^{-1}$ or $1.01 \mathrm{mmol} \mathrm{g}^{-1}$, in comparison to $462 \mathrm{mg} \mathrm{g}^{-1}$ or $1.04 \mathrm{mmol} \mathrm{g}{ }^{-1}$ for TC adsorption on SAz-1 (Li et al. 2010). The TC adsorption capacity value is almost 200 times larger than TC adsorption on two surface soils (an Alfisol and Ultisol) collected from Tianjiin (Bao et al. 2010), but is comparable to that on activated carbon of 0.5 and $1.5 \mathrm{mmol} \mathrm{g}^{-1}$ (Chen et al. 2011).

\section{Kinetics of TC desorption}

The results of TC desorption from initial loadings of 37, 183 , and $356 \mathrm{mg} \mathrm{g}^{-1}$ were fitted to several kinetic models including pseudo-first-order, pseudo-second-order, and the Elovich models, and the pseudo-second-order kinetic model fitted the data best (Fig. 3). This model was widely applied to the adsorption and desorption of pollutants from

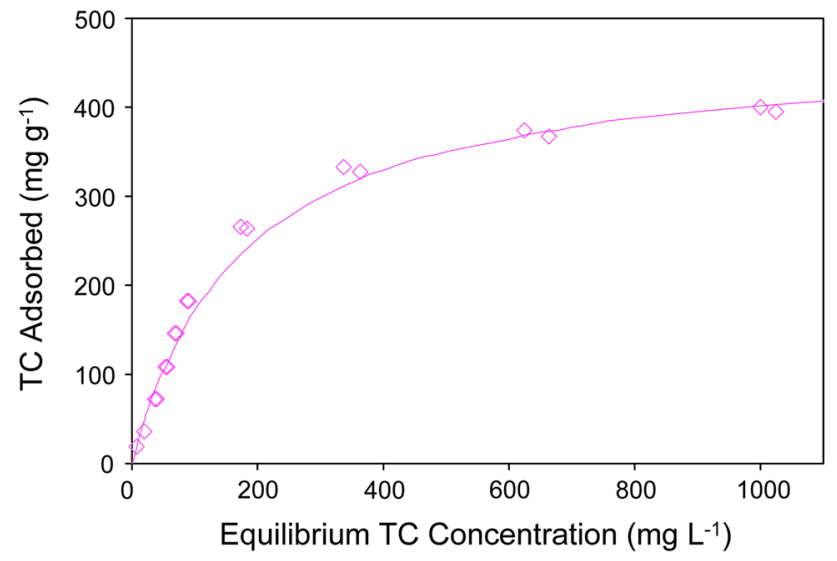

Fig. 2 TC adsorption on SAz-2. The solid line is the Langmuir fit to the observed data with a TC adsorption capacity of $449 \mathrm{mg} \mathrm{g}^{-1}$ or $1.01 \mathrm{mmol} \mathrm{g}^{-1}$ aqueous solutions in recent years (Ho and Mckay 1999). The integrated rate law was:

$q_{t}=\frac{k q_{e}^{2} t}{1+k q_{e} t}$

where $k\left(\mathrm{~g} \mathrm{mg}^{-1} \mathrm{~h}^{-1}\right)$ is the rate constant of desorption, $q_{e}$ $\left(\mathrm{mg} \mathrm{g}^{-1}\right)$ is the amount of TC desorbed at equilibrium, and $q_{t}\left(\mathrm{mg} \mathrm{g}^{-1}\right)$ is the amount of TC desorbed o at any time, $t$. Equation (1) can be re-arranged into a linear form

$\frac{t}{q_{t}}=\frac{1}{k q_{e}^{2}}+\frac{1}{q_{e}} t$

The coefficient of determination $r^{2}$ was no less than 0.999 when $\mathrm{AlCl}_{3}, \mathrm{CaCl}_{2}$, or $\mathrm{NaCl}$ was used as the
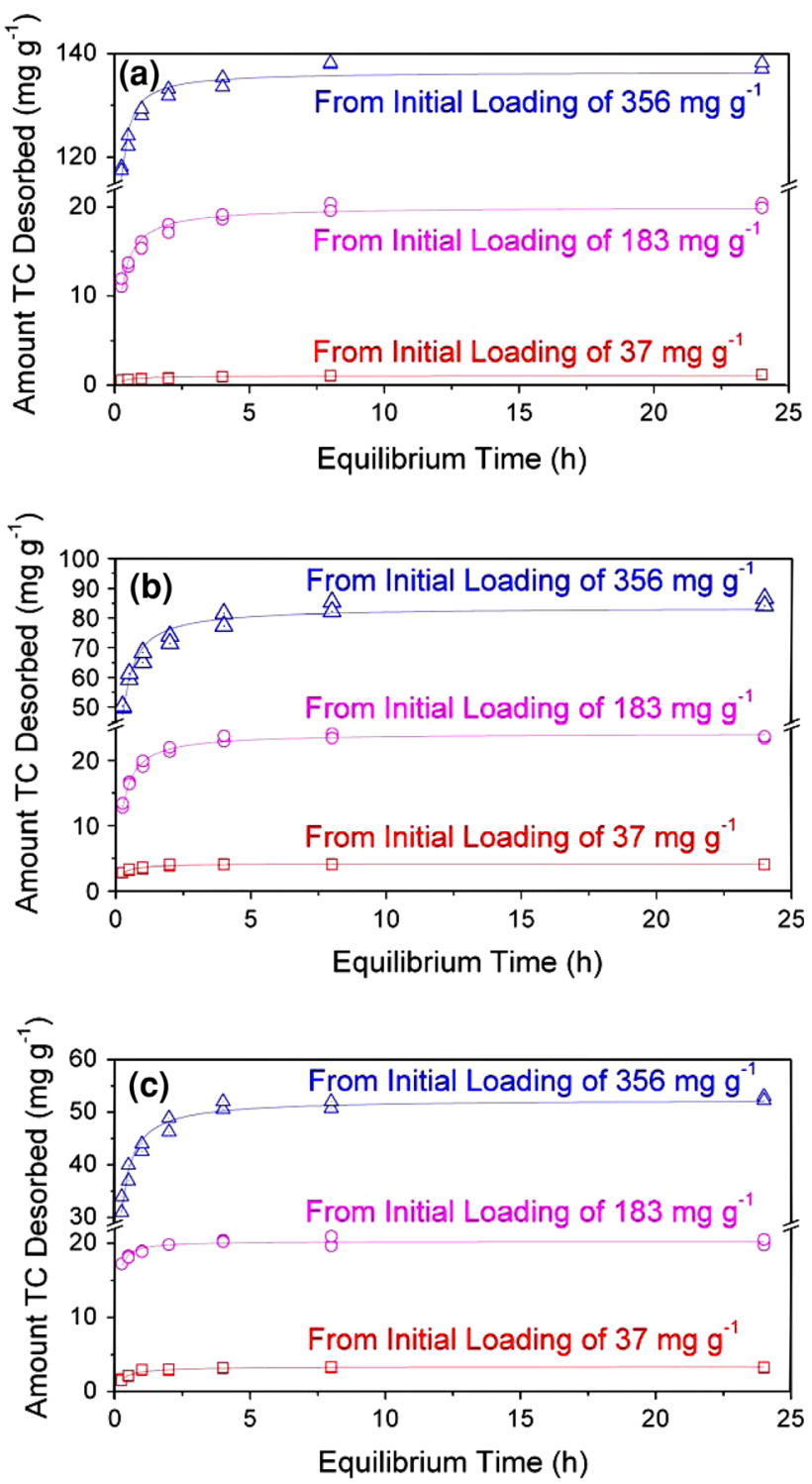

Fig. 3 Desorption kinetics of TC from SAz-2 by $0.05 \mathrm{M} \mathrm{AlCl}_{3}(\mathbf{a})$, $\mathrm{CaCl}_{2}(\mathbf{b})$, and $\mathrm{NaCl}(\mathbf{c})$. The solid lines are pseudo-second-order fit to the observed data 
desorbing reagent. The fitted results were listed in Table 1 . Overall, for each desorbing reagent, the initial rate increased as the initial TC loading on SAz-2 increased. On the other hand, the rate constant deceased as the initial loading increased (Table 1). The higher rate constants for TC desorption from SAz-2 at an initial loading of $37 \mathrm{mg} \mathrm{g}^{-1}$ indicated that removal was probably from the external surfaces of SAz-2. At an initial TC loading of $356 \mathrm{mg} \mathrm{g}^{-1}$, the initial rate for $\mathrm{TC}$ removal by $\mathrm{Al}^{3+}$ was $2,000 \mathrm{mg} \mathrm{g}^{-1} \mathrm{~h}^{-1}$ much faster than those by the other two cations. The rate constant and $q_{e}$ were also higher when $\mathrm{Al}^{3+}$ was the desorbing reagent. This phenomenon could be interpreted by the charge effect, as in a cation exchange reaction smaller cationic sizes with higher charges had a preferred affinity over large cations with lower charges on soil surfaces. Figure 3 also showed that a minimum of $6 \mathrm{~h}$ was needed for TC desorption to reach equilibrium.

\section{Equilibrium TC desorption from SAz-2}

The presence of cations in the soil solution, especially $\mathrm{CaCl}_{2}$, can significantly reduce TC adsorption on soils as well as the nonlinearity of the adsorption isotherms (Bao et al. 2010). In the absence of $\mathrm{Ca}^{2+}$, TC adsorption was high at low $\mathrm{pH}$ and decreased as the $\mathrm{pH}$ increases, while in the presence of $\mathrm{Ca}^{2+}$, TC adsorption decreased at low $\mathrm{pH}$ and increased at high pH (Parolo et al. 2012). TC desorption increased as the initial TC adsorption on SAz-2 increased (Fig. 4). When the initial TC loading was less than $200 \mathrm{mg} \mathrm{g}^{-1}$, the amount of TC desorbed was low, resulting in a ratio of the amount of TC desorbed to that of initial adsorbed less than $1 / 8$. Beyond $200 \mathrm{mg} \mathrm{g}^{-1}$, significant amounts of TC desorbed. The ratio of the amount of TC desorbed to that of initially adsorbed was as high as $1 / 3$. This trend may suggest two sorption sites for TC uptake with the first being the internal and the second being external. And at a higher initial TC loading, much of the TC desorption was from the external sites on SAz-2.

At the initial TC adsorption of $400 \mathrm{mg} \mathrm{g}^{-1}$, TC desorption was $133 \pm 4,83 \pm 6$, and $50 \pm 4 \mathrm{mg} \mathrm{g}^{-1}$, respectively, when $0.05 \mathrm{M} \mathrm{Al}^{3+}, \mathrm{Ca}^{2+}$, and $\mathrm{Na}^{+}$were used as desorbing reagents, agreeing well with the desorption kinetic study. The results indicated that with an equal initial concentration, cations with high charge could desorb more TC in comparison to low charged ones. However, after the concentrations of desorbing reagents were normalized to charge equivalency, the amount of TC desorbed would be about 44,42 , and $50 \mathrm{mg} \mathrm{g}^{-1}$ or $11-14 \%$ per $10 \mathrm{mmol}$ of charge. In studying adsorption and desorption of TC on marine sediment a positive hysteresis was observed, suggesting that some of the adsorbed TC was tightly bound to the sediment particles and did not readily desorb ( $\mathrm{Xu}$ and $\mathrm{Li}$ 2010). However, the mechanism resulting in such hysteresis was not identified. The results from this study further confirmed that cation exchange is the major mechanism for TC desorption from SAz-2.

\section{Effect of $\mathrm{pH}$ on TC desorption}

The $\mathrm{pH}$ of a solution is an important factor that can affect the form and quantity of TC in water. When the equilibrium solution $\mathrm{pH}$ was below the $\mathrm{pK}_{\mathrm{a} 2}$ of $\mathrm{TC}$, the amount of TC desorbed varied from 1 to $12 \mathrm{mg} \mathrm{g}^{-1}$ and 15 to $43 \mathrm{mg} \mathrm{g}^{-1}$ at initial TC loadings of 187 and $400 \mathrm{mg} \mathrm{g}^{-1}$, respectively (Fig. 5). TC desorption increased sharply from 26 to $157 \mathrm{mg} \mathrm{g}^{-1}$ and from 50 to $280 \mathrm{mg} \mathrm{g}^{-1}$ as the solution $\mathrm{pH}$ increased from 7 to 11 . The amount of TC desorbed followed the order of $\mathrm{Ca}^{2+}>\mathrm{Na}^{+}>\mathrm{Al}^{3+}$ at lower loading levels, but the order changed to $\mathrm{Al}^{3+}>\mathrm{Ca}^{2+}>\mathrm{Na}^{+}$at higher initial TC loading levels (Fig. 5). At pH 11, about $79 \%$ of previously adsorbed TC was desorbed.

Table 1 The kinetic parameters of TC desorption from SAz-2 at different loading levels by $\mathrm{AlCl}_{3}, \mathrm{CaCl}_{2}$, and $\mathrm{NaCl}$

\begin{tabular}{|c|c|c|c|c|c|c|}
\hline $\begin{array}{l}\text { Initial TC loading } \\
\left(\mathrm{mg} \mathrm{g}^{-1)}\right.\end{array}$ & $\begin{array}{l}\text { Desorbing } \\
\text { reagent }\end{array}$ & $\begin{array}{l}\text { Initial rate } \\
\left(\mathrm{mg} \mathrm{g}^{-1} \mathrm{~h}^{-1}\right)\end{array}$ & $\begin{array}{l}\text { Rate constant } \\
\left(\mathrm{g} \mathrm{mg}^{-1} \mathrm{~h}^{-1}\right)\end{array}$ & $q_{e}\left(\mathrm{mg} \mathrm{g}^{-1}\right)$ & $r^{2}$ & $\begin{array}{l}\text { Time to reach } \\
\text { equilibrium }(\mathrm{h})\end{array}$ \\
\hline \multirow[t]{3}{*}{356} & $\mathrm{AlCl}_{3}$ & 2,000 & 0.1 & 139 & 1 & 6 \\
\hline & $\mathrm{CaCl}_{2}$ & 313 & 0.19 & 86 & 1 & 6 \\
\hline & $\mathrm{NaCl}$ & 263 & 0.09 & 53 & 1 & 6 \\
\hline \multirow[t]{3}{*}{183} & $\mathrm{AlCl}_{3}$ & 78 & 0.1 & 20 & 1 & 6 \\
\hline & $\mathrm{CaCl}_{2}$ & 147 & 0.26 & 23 & 1 & 6 \\
\hline & $\mathrm{NaCl}$ & 769 & 0.09 & 20 & 0.999 & 6 \\
\hline \multirow[t]{3}{*}{37} & $\mathrm{AlCl}_{3}$ & 1.7 & 1.1 & 1.2 & 0.998 & 6 \\
\hline & $\mathrm{CaCl}_{2}$ & 48 & 2.8 & 4.2 & 1 & 6 \\
\hline & $\mathrm{NaCl}$ & 21 & 2 & 3.2 & 0.999 & 6 \\
\hline
\end{tabular}

The solution $\mathrm{pH}$ was in the range of $3.5-4.6$ 


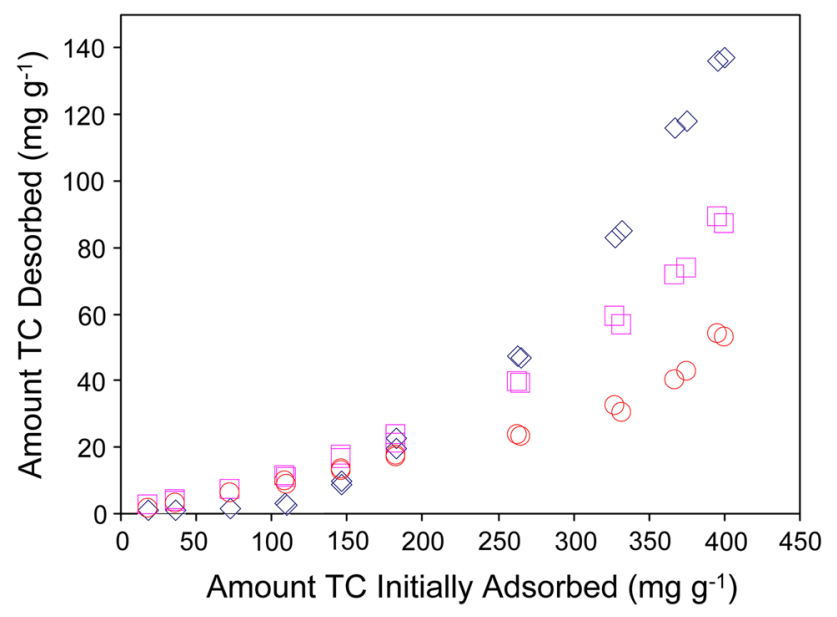

Fig. 4 TC desorption from SAz-2 at different initial loadings by $\mathrm{AlCl}_{3}$ (diamond), $\mathrm{CaCl}_{2}$ (square), and $\mathrm{NaCl}$ (circle)

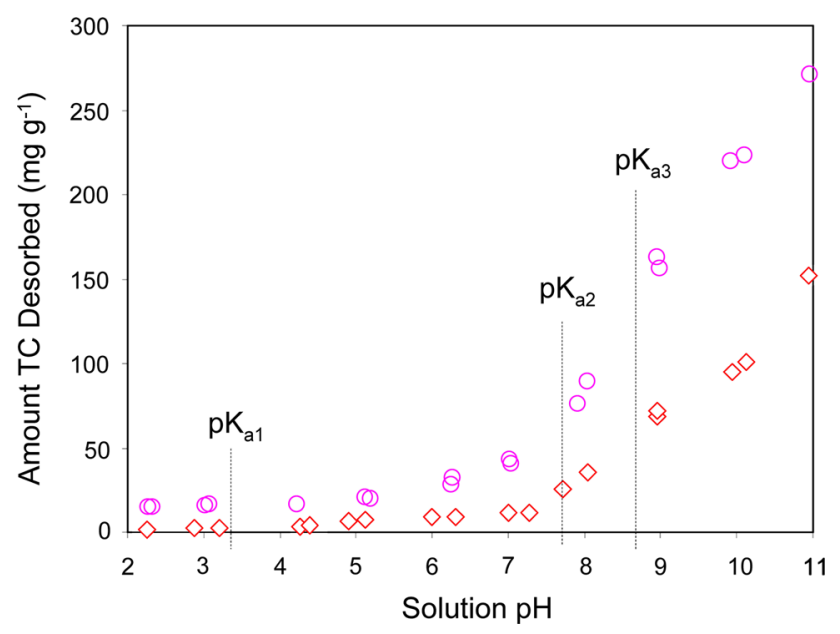

Fig. 5 TC desorption from SAz-2 as affected by solution $\mathrm{pH}$ at initial TC loadings of $187 \mathrm{mg} \mathrm{g}^{-1}$ (diamond) and $400 \mathrm{mg} \mathrm{g}^{-1}$ (circle)

Previous research showed that TC adsorption decreased significantly when solution $\mathrm{pH}$ was greater than the $\mathrm{pK}_{\mathrm{a} 2}$ of TC (Miller et al. 1977). Little of the adsorbed TC or chlortetracycline was desorbed under $\mathrm{pH} 5.8$ and 7 with only up to $1.0 \%$ desorption observed from clay-humic acid complex, suggesting that interactions between clays and humic substances not only reduce TC adsorption but may also enhance TC desorption (Pils and Laird 2007). The trend of TC desorption in this study agreed well with the decreased TC adsorption in the presence of $0.01 \mathrm{M} \mathrm{NaCl}$ as solution $\mathrm{pH}$ increases (Parolo et al. 2012). However, the results from this study differed from TC adsorption in the presence of $0.01 \mathrm{M} \mathrm{CaCl}_{2}$ (Parolo et al. 2012), in which they reported an increase in TC adsorption by increasing $\mathrm{pH}$ from 5 to 7, which was attributed to Ca-bridging as the prevailing mechanism. Similar results were reported by Zhao et al. (2012). The partitioning coefficient $\left(K_{d}\right)$ of TC between soild and liquid was significantly reduced when TC was adsorbed from $0.01 \mathrm{~N} \mathrm{KCl}$ or $\mathrm{NaCl}$ solution in comparison to that from $0.01 \mathrm{~N} \mathrm{CaCl}_{2}$ solution onto smectite-dominated soils at nearly neutral $\mathrm{pH}$ and very low equilibrium TC concentrations (Sassman and Lee 2005).

$\mathrm{Al}^{3+}$ is the prevailing ion at $\mathrm{pH}<5$ while the aqueous $\mathrm{Al}(\mathrm{OH})^{2+}, \mathrm{Al}(\mathrm{OH})_{2}^{+}, \mathrm{Al}(\mathrm{OH})_{3}$, and $\mathrm{Al}(\mathrm{OH})_{4}^{-}$appear as prevailing species at $\mathrm{pH}>5$. Calculation of total dissolved $\mathrm{Al}$ as a function of solution $\mathrm{pH}$ showed that precipitation would occur at $\mathrm{pH} 4.05-10.6$. To confirm the calculation, we performed an additional experiment to prepare $1,000 \mathrm{mg} \mathrm{g}^{-1}$ TC solution under different solution $\mathrm{pH}$ conditions. Our results showed precipitation indeed occurred at solution $\mathrm{pH} 5-10$. Both the supernatant and the precipitates were analyzed by FTIR to investigate the association of TC with $\mathrm{Al}$ precipitate. Indeed, precipitation incorporated certain amount of $\mathrm{TC}$, which could be attributed to the less TC desorption in the $\mathrm{pH}$ range of 5-7 as illustrated in Fig. 5. However, TC desorption was low (Fig. 5) at $\mathrm{pH} \mathrm{2-4}$ at which no precipitation was found. And TC desorption increased significantly at $\mathrm{pH} 7-10$ even though precipitation was observed in the new experiment. Thus, we believe that solubility of Al played a role in TC desorption, but not as much as the solution $\mathrm{pH}$, i.e., not as much as the concentrations of $\mathrm{H}^{+}$or $\mathrm{OH}^{-}$in solution.
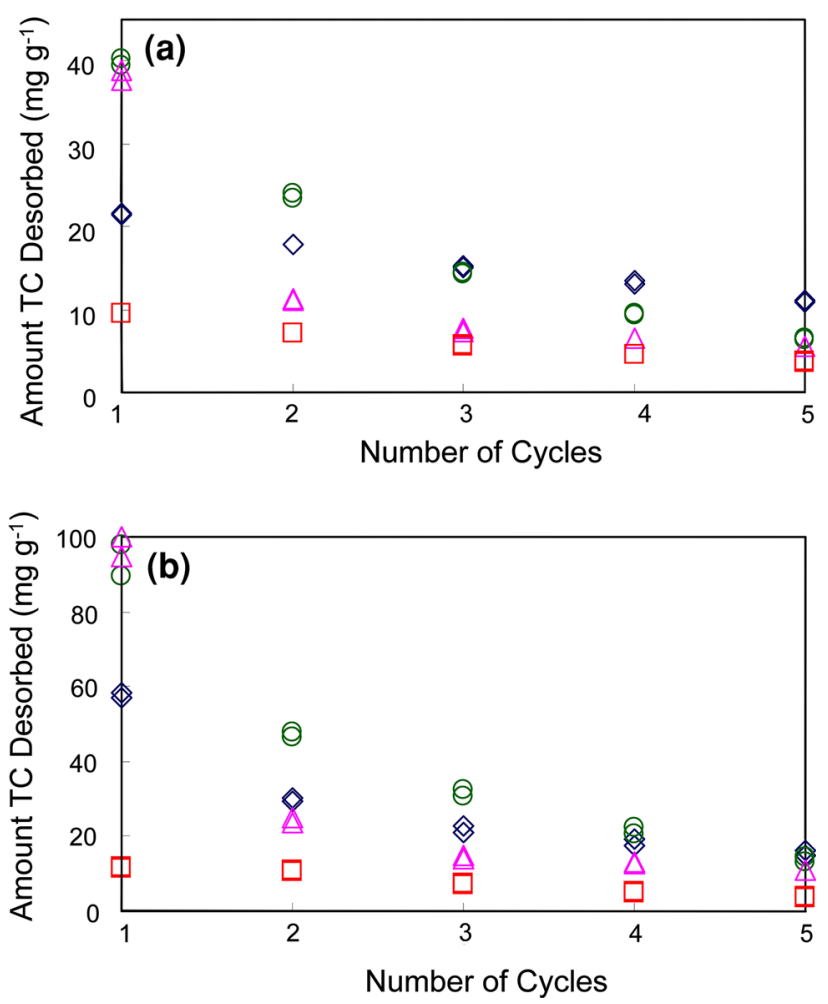

Fig. $6 \mathrm{TC}$ removal by $\mathrm{AlCl}_{3}$ (triangle), $\mathrm{CaCl}_{2}$ (circle), $\mathrm{NaCl}$ (diamond), and distilled water (square) under different desorption cycles at initial TC loadings of $187 \mathrm{mg} \mathrm{g}^{-1}$ (a) and $400 \mathrm{mg} \mathrm{g}^{-1}$ (b) 
Effect of repetitive desorption

When $\mathrm{Al}^{3+}$ was present, the highest amount of TC desorbed from SAz-2 loaded with 187 and $400 \mathrm{mg} \mathrm{g}^{-1}$ of TC occurred in the first desorption cycle, corresponding to 22 and $28 \%$ of the initially adsorbed amounts (Fig. 6). The total amounts of TC desorbed after five desorption cycles was 56 and $152 \mathrm{mg} \mathrm{g}^{-1}$, respectively, corresponding to 30 and $38 \%$ of the initial TC loading (Table 2). Similar TC desorption was observed when $\mathrm{Ca}^{2+}$ was present, except that the total TC desorbed was 51 and $58 \%$. For $\mathrm{Na}^{+}$, TC desorption was 37 and $47 \%$ after five desorption cycles. The fact that less TC was desorbed in the second to fifth desorption cycles by $\mathrm{Al}^{3+}$ in comparison to $\mathrm{Ca}^{2+}$ and $\mathrm{Na}^{+}$could be attributed to $\mathrm{Al}(\mathrm{OH})_{3}$ precipitation in subsequent desorption cycles, due to an increased input of $\mathrm{Al}^{3+}$. This increase of total $\mathrm{Al}^{3+}$ input could significantly increase the amount of $\mathrm{Al}(\mathrm{OH})_{3}$ precipitation which enhanced $\mathrm{TC}$ adsorption on its surface instead of clay minerals. However, the separation of solid from the liquid during the centrifugation process resulted in a net removal of TC from solution, thus less apparent TC desorption. In contrast to using electrolyte solutions, distilled water only removed 11 and $18 \%$ of the total adsorbed TC after five desorption cycles. A systematic decrease in the amount of TC desorbed as the number of repetitive desorption increased, reflecting progressive difficulties in TC removal from the external surfaces or interlayer spaces of SAz-2.

\section{XRD analyses}

Swelling clays such as montmorillonite are unique in that their $c$-axis spacing $\left(d_{001}\right)$ adapts to the intercalated molecule when internal adsorption occurs. Changes in this parameter can be detected by X-ray diffraction. Previous studies showed that the $d$-spacing of swelling clays such as SHCa-1, SAz-1, SWy-2, and SYn-1 changed after adsorption of TC (Li et al. 2010). Similar to other swelling clays, the $d$-spacing increased accordingly after progressive adsorption and intercalation of TC into SAz-2 (Fig. 7a-c). At the TC loading level of $19 \mathrm{mg} \mathrm{g}^{-1}$, the desorption using $\mathrm{Al}^{3+}, \mathrm{Ca}^{2+}, \mathrm{Na}^{+}$, and another cationic drug CIP at a concentration of $1,000 \mathrm{mg} \mathrm{L}^{-1}$ resulted in some changes in $d$-spacing (Fig. 7a). Previous results showed that at an initial CIP concentration of $1,000 \mathrm{mg} \mathrm{L}^{-1}$, the amount of CIP adsorbed was $200 \mathrm{mg} \mathrm{g}^{-1}$ (Wu et al. 2010). Thus, the change in $d$-spacing could be attributed to further intercalation of CIP into the interlayer of montmorillonite, as more sorption sites are still available in the interlayer. Similarly, at the TC adsorption level of $150 \mathrm{mg} \mathrm{g}^{-1}$, there were still more sorption sites available for CIP uptake even if no TC would be desorbed, resulting in further expansion of $d$-spacing as the total amount of CIP and TC adsorbed could be about $350 \mathrm{mg} \mathrm{g}^{-1}$, if no or minute amounts of TC was desorbed using CIP (Fig. 7b). Finally, at a high TC loading level of $332 \mathrm{mg} \mathrm{g}^{-1}$, the $d$-spacing remained almost constant at $22 \AA$ (Fig. 7c). The $d$-spacing remained the same after SAz-2 was desorbed by $\mathrm{AlCl}_{3}, \mathrm{CaCl}_{2}$, and $\mathrm{NaCl}$ at different times (Fig. 7d-f) and different desorption cycles (Fig. $7 \mathrm{~g}-\mathrm{j}$ ). The nearly constant $d$-spacing regardless of the desorbing agents used suggested that replacement of TC by the inorganic and organic cations under neutral $\mathrm{pH}$ condition was less likely favored.

A slight expansion of $d_{001}$-spacing after desorption by CIP was visible in all TC adsorption range. Because the initial TC adsorption was only 19 and $150 \mathrm{mg} \mathrm{g}^{-1}$, the use of CIP as the desorbing reagent could result in intercalation of CIP molecules in the interlayer of SAz-2, thus resulting in further expansion of $d$-spacing (Fig. 7a, b). The shape of the (001) peak became narrower and the intensity increased after desorption by CIP, further indicated that intercalated TC may adopt disordered arrangement in the interlayer space and the adsorption of CIP resulted in more ordered arrangement. The invariable FTIR spectra of enrofloxacin sorption on and desorption from smectite was attributed to

Table 2 The TC desorption ( $\mathrm{mg} \mathrm{g}^{-1}$ ) using $0.05 \mathrm{M} \mathrm{AlCl}_{3}, \mathrm{CaCl}_{2}, \mathrm{NaCl}$, and distilled water from SAz-2 at initial TC loading levels of 187 and $400 \mathrm{mg} \mathrm{g}^{-1}$, respectively

\begin{tabular}{|c|c|c|c|c|c|c|c|c|}
\hline \multirow[t]{2}{*}{ Desorption cycle } & \multicolumn{4}{|c|}{ Desorption from $187 \mathrm{mg} \mathrm{g}^{-1}$} & \multicolumn{4}{|c|}{ Desorption from $400 \mathrm{mg} \mathrm{g}^{-1}$} \\
\hline & $\mathrm{Al}^{3+}$ & $\mathrm{Ca}^{2+}$ & $\mathrm{Na}^{+}$ & Water & $\mathrm{Al}^{3+}$ & $\mathrm{Ca}^{2+}$ & $\mathrm{Na}^{+}$ & Water \\
\hline 1 & 19 & 27 & 16 & 8 & 93 & 84 & 51 & 12 \\
\hline 2 & 13 & 19 & 14 & 7 & 23 & 43 & 30 & 11 \\
\hline 3 & 9 & 13 & 13 & 5 & 15 & 31 & 22 & 7 \\
\hline 4 & 8 & 9 & 11 & 3 & 11 & 20 & 17 & 5 \\
\hline 5 & 7 & 6 & 9 & 3 & 10 & 14 & 14 & 4 \\
\hline Total $\left(\mathrm{mg} \mathrm{g}^{-1}\right)$ & 56 & 73 & 63 & 26 & 152 & 192 & 134 & 39 \\
\hline
\end{tabular}

The solution $\mathrm{pH}$ was in the range of $3.5-4.6$ 

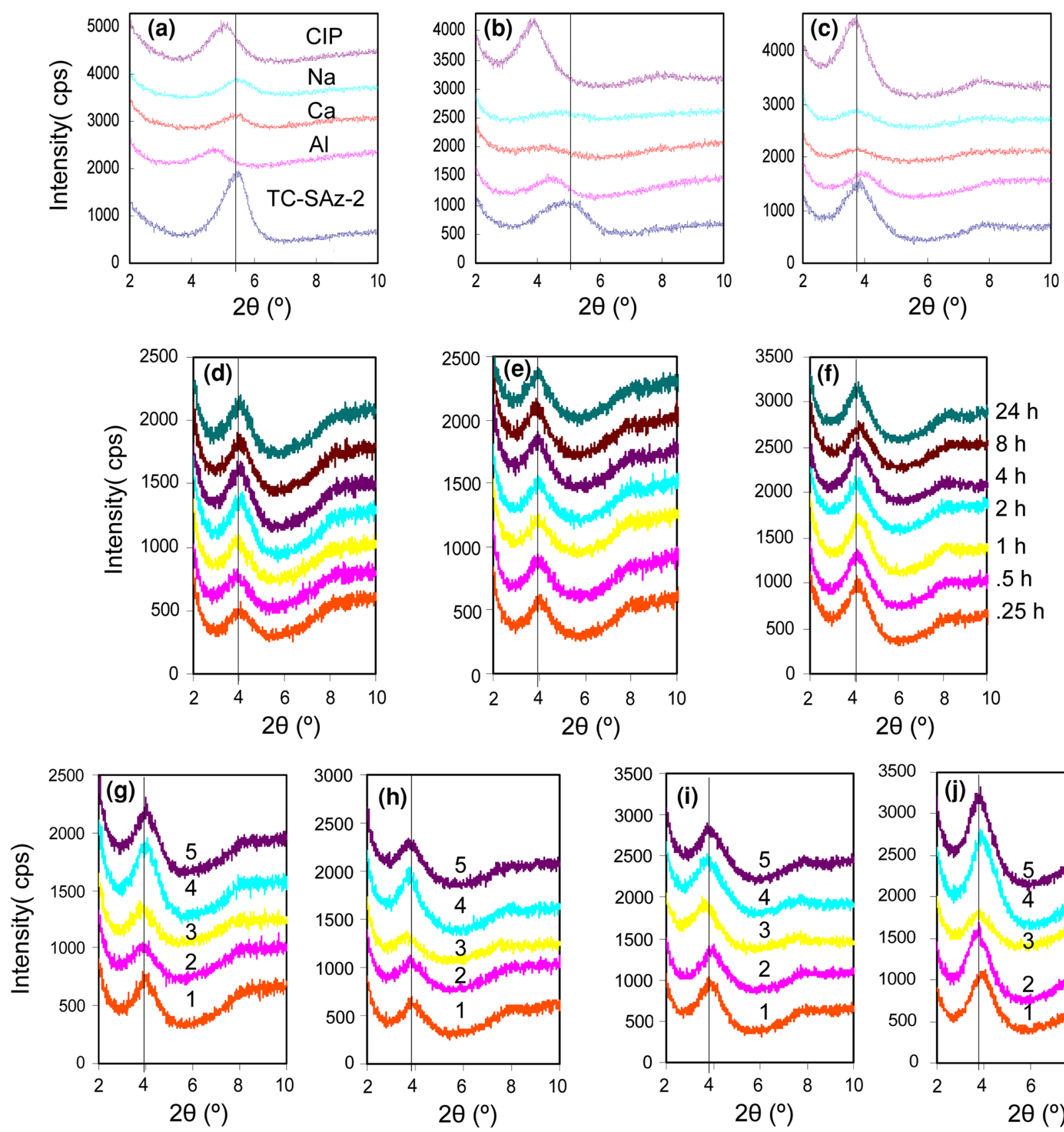

Fig. 7 X-ray diffraction patterns of SAz-2 desorbed by different agents from SAz-2 at TC loading levels of 19 (a), 150 (b), and $332 \mathrm{mg} \mathrm{g}^{-1}$ (c); desorbed by $0.05 \mathrm{M} \mathrm{AlCl}_{3}(\mathbf{d}), \mathrm{CaCl}_{2}$ (e), and $\mathrm{NaCl}$
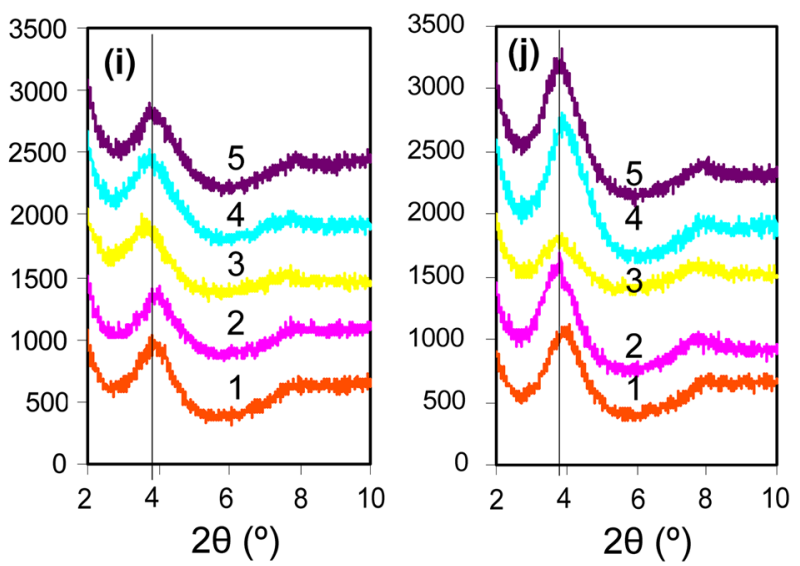

(f) at different time; desorbed by $0.05 \mathrm{M} \mathrm{AlCl}_{3}(\mathbf{g}), \mathrm{CaCl}_{2}$ (h), $\mathrm{NaCl}$ (i), and water (j) under different desorption cycles

inner sphere sorption (Yan et al. 2012). Due to the lack of XRD results after desorption (Yan et al. 2012) it was difficult to determine whether the removal of enrofloxacin was from the external surfaces or from the interlayer space of smectite. The XRD patterns in this study gave strong evidences that TC intercalation in SAz-2 was very stable while the desorbed TC almost all came from the external surfaces of SAz-2.

FTIR analyses

The SAz-2 samples after each desorption cycle from an initial TC loading of $400 \mathrm{mg} \mathrm{g}^{-1}$ were further analyzed using FTIR. The band location for crystalline TC and TC-adsorbed SAz-2 after each desorption cycle by different desorbing reagents were listed in Table 3 . Most of the bands were assigned to more than one types of vibration 
Table 3 FTIR band positions $\left(\mathrm{cm}^{-1}\right)$ for crystalline TC and TC-intercalated SAz-2 at an initial loading of $400 \mathrm{mg} \mathrm{g}^{-1}$ after desorbing with different metal cations ( $\mathrm{Gu}$ and

Karthikeyan 2005; Leypold et al. 2003)

Gu and Karthikeyan (2005)

Fig. 8 FTIR spectra of TCadsorbed SAz-2 after different cycles of desorption by $\mathrm{AlCl}_{3}$ (a), $\mathrm{CaCl}_{2}$ (b), $\mathrm{NaCl}$ (c), and distilled water $(\mathbf{d})$. The initial TC loading was $400 \mathrm{mg} \mathrm{g}^{-1}$. The numbers indicate desorption cycles and the bottom spectrum in each figure is from crystalline TC with the transmittance on the right $y$-axis

\begin{tabular}{|c|c|c|c|c|c|}
\hline $\begin{array}{l}\text { Crystalline } \\
\text { TC }\end{array}$ & $\mathrm{Al}^{3+}$ & $\mathrm{Ca}^{2+}$ & $\mathrm{Na}^{+}$ & $\begin{array}{l}\text { Deionized } \\
\text { water }\end{array}$ & Possible band assignment (Leypold et al. 2003) \\
\hline 1,676 & - & - & - & - & $\mathrm{C}=\mathrm{O}$ amide $^{\mathrm{a}}$ \\
\hline 1,614 & 1,645 & 1,633 & 1,633 & 1,633 & $\begin{array}{l}v(\mathrm{CO} 1), v(\text { amid-CO }), \delta(\text { amid-NH }), v(\mathrm{CO} 3) \\
v(\mathrm{C} 2 \mathrm{C} 3), \delta(\mathrm{OH} 10,12) \text { or } \mathrm{C}=\mathrm{O} \text { in ring } \mathrm{A}^{\mathrm{a}}\end{array}$ \\
\hline 1,579 & 1,596 & Shoulder & 1,585 & 1,585 & $\begin{array}{c}\delta(\text { amid-NH }), \delta(\text { amine- } \mathrm{NH}), v(\text { Amid-CO }), v(\mathrm{C} 2 \mathrm{C} 3), \\
v(\mathrm{CO} 3) \text { or } \mathrm{C}=\mathrm{O} \text { in ring } \mathrm{C}^{\mathrm{a}}\end{array}$ \\
\hline 1,518 & 1,500 & 1,509 & 1,518 & 1,518 & $\mathrm{NH}_{2}$ amide $^{\mathrm{a}}$ \\
\hline 1,455 & 1,473 & 1,455 & 1,544 & 1,455 & $\begin{array}{l}\delta(\mathrm{OH} 10,12), \delta(\mathrm{CH} 7,8,9), v(\mathrm{D}), v(\mathrm{CO} 10, \mathrm{CO} 11) \\
\quad v(\mathrm{C} 11 \mathrm{C} 11 \mathrm{a}, \mathrm{C} 11 \mathrm{aC} 12), \delta(\mathrm{OH} 12 \mathrm{a}), \delta(\mathrm{CH} 36) \text { or } \\
\mathrm{C}=\mathrm{C} \text { skeleton }^{\mathrm{a}}\end{array}$ \\
\hline 1,380 & - & - & - & - & \\
\hline 1,355 & 1,400 & 1,400 & 1,400 & 1,400 & $\begin{array}{l}v(\text { amid-C,C2 }), v(\mathrm{C} 3, \mathrm{C} 4), \delta(\mathrm{CH} 4 \mathrm{a}, 5), \\
\delta(\mathrm{CH} 36), \delta(\mathrm{OH} 12 \mathrm{a}), \delta(\text { amid-NH }), v(\text { amid-CN }), \\
\quad \delta(\mathrm{OH} 10), v(\mathrm{C} 6 \mathrm{aC} 10 \mathrm{a}, \mathrm{C} 6 \mathrm{aC} 7)\end{array}$ \\
\hline 1,309 & 1,326 & 1,332 & 1,332 & 1,332 & $\begin{array}{l}\delta(\mathrm{OH} 10,12), \delta(\mathrm{CH} 4,4 \mathrm{a}, 5,5 \mathrm{a}), v(\mathrm{C} 5 \mathrm{aC} 11 \mathrm{a}), \\
\quad v(\mathrm{C} 1 \mathrm{C} 2), v(\mathrm{C} 9 \mathrm{C} 10, \mathrm{C} 10 \mathrm{C} 10 \mathrm{a}, \mathrm{C} 10 \mathrm{aC} 11), \\
\quad v(\mathrm{CO} 11,12), v(\mathrm{CO} 3), \delta(\mathrm{CH} 7,8,9)\end{array}$ \\
\hline 1,246 & - & - & - & - & \\
\hline 1,226 & 1,240 & 1,246 & 1,246 & 1,246 & \\
\hline
\end{tabular}
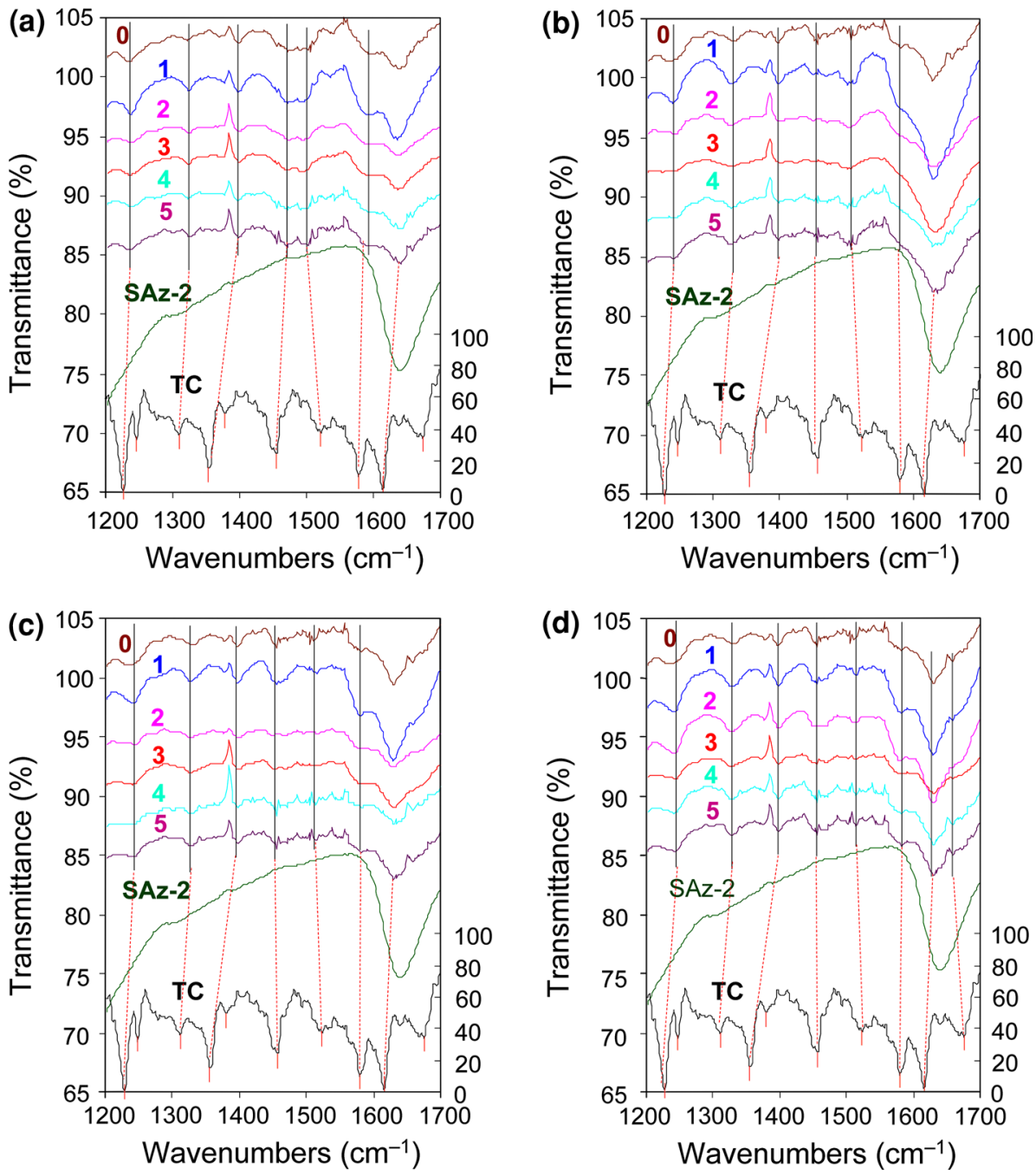
(Leypold et al. 2003). Overall, neither the band location nor the band intensity had drastic changes among these desorption cycles (Fig. 8). However, the band positions for TC desorbed with different reagents were not the same.

The carbonyl vibration associated with ketone and amide bands occurring at $1,685 \mathrm{~cm}^{-1}$ for oxytetracycline shifted to a lower frequency at $1,665 \mathrm{~cm}^{-1}$, and was hidden under the alkene/aromatic band and amide II band occur at 1,625 and $1,587 \mathrm{~cm}^{-1}$, respectively (Kulshrestha et al. 2004). This was attributed to the coordination of carbonyl group directly with the interlayer cations or hydrogen bonded with hydroxyl groups of the water coordinated to the interlayer cation (Kulshrestha et al. 2004). In this study, this band was at $1,676 \mathrm{~cm}^{-1}$ for crystalline TC and was not resolved when TC was adsorbed on SAz-2.

For TC, the $\mathrm{C}=\mathrm{O}$ in ring A occurred at $1,614 \mathrm{~cm}^{-1}$. The $\mathrm{OH}$ deformation of water of raw SAz-2 was at $1,645 \mathrm{~cm}^{-1}$. For TC adsorbed SAz-2, a composite band showed up at $1,633 \mathrm{~cm}^{-1}$. The band remained at $1,633 \mathrm{~cm}^{-1}$ after repetitive desorption by deionized water, $\mathrm{Na}^{+}$, and $\mathrm{Ca}^{2+}$. The band shifted progressive from 1,643 to $1,645 \mathrm{~cm}^{-1}$ as the number of desorption cycle by $\mathrm{Al}^{3+}$ increased (Fig. 8a), reflecting a strong interaction between the $\mathrm{C}=\mathrm{O}$ in ring $\mathrm{A}$ and $\mathrm{Al}^{3+}$.

The band at $1,578 \mathrm{~cm}^{-1}$ corresponding to the carbonyl groups in ring $\mathrm{C}$ gradually changed into a shoulder and eventually disappeared after repetitive desorption by $\mathrm{Ca}^{2+}$ (Fig. 8b). This may indicate that progressive replacement of $\mathrm{Ca}^{2+}$ for $\mathrm{TC}^{+}$weakened the interaction between $\mathrm{Ca}^{2+}$ and $\mathrm{TC}^{+}$in the interlayer. The band shifted to $1,585 \mathrm{~cm}^{-1}$, suggesting that TC complexation with SAz-2 could be occurring at the carbonyl (C-11 in ring $\mathrm{C}$ ) (Gu and Karthikeyan 2005) when Deionized water and $\mathrm{Na}^{+}$were used as the desorbing reagents (Fig. 8c, d). The band further shifted to $1,596 \mathrm{~cm}^{-1}$ when $\mathrm{Al}^{3+}$ was used as the desorbing reagent (Fig. 8a). This result again suggested that the replacement of some $\mathrm{Al}^{3+}$ for $\mathrm{TC}^{+}$in the interlayer may induce the formation of strong $\mathrm{Al}^{3+}$ and TC complex in the interlayer.

The band at $1,518 \mathrm{~cm}^{-1}$ was assigned to vibration of $\mathrm{NH}_{2}$ amide (Gu and Karthikeyan 2005). It remained the same after desorption with deionized water and $\mathrm{Na}^{+}$, but decreased to $1,509 \mathrm{~cm}^{-1}$ after desorption with $\mathrm{Ca}^{2+}$ and further decreased to $1,500 \mathrm{~cm}^{-1}$ after desorption with $\mathrm{Al}^{3+}$ (Fig. 8). Overall, the intensity of this band decreased systematically as the number of desorption cycles increased. The $1,455 \mathrm{~cm}^{-1}$ vibration attributed to $\mathrm{C}=\mathrm{C}$ skeleton $(\mathrm{Gu}$ and Karthikeyan 2005) remained the same after desorption with deionized water, $\mathrm{Na}^{+}$, and $\mathrm{Ca}^{2+}$, but increased to $1,473 \mathrm{~cm}^{-1}$ after desorption with $\mathrm{Al}^{3+}$.
The band at $1,355 \mathrm{~cm}^{-1}$ shifted to $1,400 \mathrm{~cm}^{-1}$ after adsorption onto $\mathrm{SAz}-2$ and remained the same after desorption by the four different types of desorbing reagents. The band at $1,309 \mathrm{~cm}^{-1}$ shifted to $1,332 \mathrm{~cm}^{-1}$ after desorption by deionized water, $\mathrm{Na}^{+}$, and $\mathrm{Ca}^{2+}$ and to $1,326 \mathrm{~cm}^{-1}$ after desorption by $\mathrm{Al}^{3+}$. The band was at $1,246 \mathrm{~cm}^{-1}$ for crystalline TC and was not resolved when TC was adsorbed on SAz-2. Meanwhile, the band at $1,226 \mathrm{~cm}^{-1}$ shifted to $1,246 \mathrm{~cm}^{-1}$ after desorption by deionized water, $\mathrm{Na}^{+}$, and $\mathrm{Ca}^{2+}$ and to $1,240 \mathrm{~cm}^{-1}$ after desorption by $\mathrm{Al}^{3+}$.

\section{Environmental implications}

Montmorillonite is one of the most important minerals present in soils and sediments. Application of animal manure containing non-degraded antibiotics may result in retention of antibiotics on the surface and in the interlayer of montmorillonite. Previous results showed that TC intercalated into the interlayer of swelling clays was thermally more stable than its crystalline counterpart (Chang et al. 2009). A similar observation was found for CIP intercalation into swelling clays (Jiang et al. 2013). The results obtained from this study suggested that TC intercalated in SAz-2 was highly stable against desorption, while the desorbed TC from SAz-2 by metal cations and organic cations largely came from the surface of the mineral rather than from the interlayer. The stable form of antibiotics retained in the interlayer and the slow release of antibiotics from the surface may induce further antibiotic resistance of the environmental microbes and even change the microbial community in the soil. Moreover, competitive sorption and interaction of various antibiotics and metal cations within swelling clays may vary in different soil and sediment environments and worth further studies.

\section{Conclusion}

The stability of adsorbed TC on a Ca-montmorillonite SAz-2 was investigated using cationic solutions of different valence charges under different $\mathrm{pH}$ conditions. Our experimental results indicated that the kinetics of TC desorption followed the pseudo-second-order kinetic model with reaction rate in the order of $\mathrm{Ca}^{2+}>\mathrm{Na}^{+}>\mathrm{Al}^{3+}$ at lower loading levels, but the order changed to $\mathrm{Al}^{3+}>\mathrm{Ca}^{2+}>\mathrm{Na}^{+}$at higher initial TC loading levels. The total amount of TC desorbed after five desorption cycles also followed the order of $\mathrm{AlCl}_{3}>\mathrm{CaCl}_{2}>\mathrm{NaCl}$, suggesting that cations with higher positive charges are 
preferred to remove adsorbed cationic drugs. The XRD patterns before and after TC desorption revealed no changes in basal spacing, even after five desorption cycles, suggesting that the removal of TC from SAz-2 was largely from the external surfaces.

Acknowledgments The financial supports from Wisconsin Ground Water Research Council and grant 100-2116-M-006-009 from National Science Council, Taiwan are greatly appreciated. The authors are thankful to the assistance of Chen Yi-Hua and Kao HsiesTa for their help in experiments.

\section{References}

Bao Y, Zhou Q, Wan Y, Yu Q, Xie X (2010) Effects of soil/solution ratios and cation types on adsorption and desorption of tetracycline in soils. Soil Sci Soc Am J 74:1553-1561

Chander Y, Kumar K, Goyal SM, Gupta SC (2005) Antibacterial activity of soil-bound antibiotics. J Environ Qual 34:1952-1957

Chang PH, Li Z, Jiang WT, Jean JS (2009) Adsorption and intercalation of tetracycline by swelling clay minerals. Appl Clay Sci 46:27-36

Chen WR, Huang CH (2010) Adsorption and transformation of tetracycline antibiotics with aluminum oxide. Chemosphere 79:779-785

Chen J, Fei Z, Tao W, Zhang G (2011) Adsorption and desorption of tetracycline on activated carbons. Adv Mater Res 233-235: $561-566$

Figueroa RA, Leonard A, Mackay AA (2004) Modeling tetracycline antibiotic sorption to clays. Environ Sci Technol 38: 476-483

Gu C, Karthikeyan KG (2005) Interaction of tetracycline with aluminum and iron hydrous oxides. Environ Sci Technol 39:2660-2667

Gu C, Karthikeyan KG (2008) Sorption of the antibiotics tetracycline to humic-mineral complexes. J Environ Qual 37:704-711

Gu C, Karthikeyan KG, Sibley SD, Pedersen JA (2007) Complexation of the antibiotic tetracycline with humic acid. Chemosphere 66:1494-1501

Halling-Sørensen B, Nors Nielsen S, Lanzky PF, Ingerslev F, Holten Lützhøft HC, Jørgensen SE (1998) Occurrence, fate, and effects of pharmaceutical substances in the environment-a review. Chemosphere 36(2):357-393

Hamscher G, Sczesny S, Höper H, Nau H (2002) Determination of persistent tetracycline residues in soil fertilized with liquid manure by high-performation liquid chromatograph with electrospray ionization tandem mass spectrometry. Anal Chem 74:1509-1518

Ho YS, McKay G (1999) Pseudo-second order model for sorption processes. Process Biochem 34:451-465

Jia D An, Zhou DM, Wang YJ, Zhu HW, Chen JL (2008) Adsorption and cosorption of $\mathrm{Cu}(\mathrm{II})$ and tetracycline on two soils with different characteristics. Geoderma 146:224-230

Jiang WT, Wang CJ, Li Z (2013) Intercalation of ciprofloxacin accompanied by dehydration in rectorite. Appl Clay Sci (in press) http://dx.doi.org/10.1016/j.clay.2012.07.009

Kay P, Boxall ABA (2000) Environmental risk assessment of veterinary medicines in slurry. SSLRC Contract JF 611OZ; Cranfield University

King AG (2006) Research advances. J Chem Educ 83:186-190
Kolpin DW, Furlong ET, Meyer MT, Thurman EM, Zauqq SD, Barber LB, Buxton HT (2002) Pharmaceuticals, hormones, and other organic wastewater contaminants in US streams, 1999-2000: a national reconnaissance. Environ Sci Technol 36: $1202-1211$

Kulshrestha P, Giese RF Jr, Aga DS (2004) Investigating the molecular interactions of oxy-tetracycline in clay and organic matter: insights on factors affecting its mobility in soil. Environ Sci Technol 38:4097-4105

Leypold CF, Reiher MG, Brehm G, Schmitt MO, Schneider S, Matousek P, Towrie M (2003) Tetracycline and derivativesassignment of IR and Raman spectra via DFT calculations. Phys. Chem. Chem. Phys. 5:1149-1157

Li Z, Chang PH, Jean JS, Jiang WT, Wang CJ (2010) Interaction between tetracycline and smectite in aqueous solution. J Colloid Interface Sci 341:311-319

Loke ML, Tjørnelund J, Halling-Sørensen B (2002) Determination of the distribution coefficient $(\log \mathrm{Kd})$ of oxytetracycline, tylosin A, olaquindox and metronidazole in manure. Chemosphere 48:351-361

Mackay AA, Canterbury B (2005) Oxytetracycline sorption to organic matter by metal-bridging. J Environ Qual 34(6):19641971

Miller GH, Smith HL, Rock WL, Hedberg S (1977) Antibacterial structure-activity relationships obtained with resistant microorganisms. I: inhibition of R-factor resistant Escherichia coli by tetracyclines. J Pharm Sci 66:88-92

Montero MT, Freixas J, Hernandez-Borrell J (1997) Expression of the partition coefficients of a homologous series of 6-fluoroquinolones. Int J Pharm 149:161-170

Parolo ME, Avena MJ, Pettinari GR, Baschini MT (2012) Influence of $\mathrm{Ca}^{2+}$ on tetracycline adsorption on montmorillonite. J Colloid Interface Sci 368:420-426

Pils JR, Laird DA (2007) Sorption of tetracycline and chlortetracycline on K- and Ca-saturated soil clays, humic substances, and clay-humic complexes. Environ Sci Technol 41:19281933

Sarmah AK, Meyer MT, Boxall AB (2006) A global perspective on the use, sales, exposure pathways, occurrence, fate and effects of veterinary antibiotics (VAs) in the environment. Chemosphere 65:725-759

Sassman S, Lee L (2005) Sorption of three tetracyclines by several soils: assessing the role of $\mathrm{pH}$ and cation exchange. Environ Sci Technol 39:7452-7459

Sibley SD, Pedersen JA (2008) Interaction of the macrolide antimicrobial clarithromycin with dissolved humic acid. Environ Sci Technol 42:422-428

Wan Y, Bao Y, Zhou Q (2010) Simultaneous adsorption and desorption of cadmium and tetracycline on cinnamon soil. Chemosphere 80:807-812

Wang YJ, Jia DA, Sun RJ, Zhu HW, Zhou DM (2008) Adsorption and cosorption of tetracycline and copper(II) on montmorillonite as affected by solution pH. Environ Sci Technol 42:32543259

Wessels JM, Ford WE, Szymczak W, Schneider S (1998) The complexation of tetracycline and anhydrotetracycline with $\mathrm{Mg}^{2+}$ and $\mathrm{Ca}^{2+}$ : a spectroscopic study. Phys. Chem. B. 102:9323-9331

Wu Q, Li Z, Hong H, Yin K, Tie L (2010) Adsorption and intercalation of ciprofloxacin on montmorillonite. Appl Clay Sci $50: 204-211$

$\mathrm{Xu}$ XR, Li XY (2010) Sorption and desorption of antibiotic tetracycline on marine sediments. Chemosphere 78:430-436

Yan W, Hu S, Jing CY (2012) Enrofloxacin sorption on smectite clays: effects of $\mathrm{pH}$, cations, and humic acid. J Colloid Interface Sci 372:141-147 
Zhao Y, Gu X, Gao S, Geng J, Wang X (2012) Adsorption of tetracycline (TC) onto montmorillonite: cations and humic acid effects. Geoderma 183-184:12-18
Zupancic M, Arcon I, Bukovec P, Kodre A (2002) A physicochemical study of the interaction of cobalt (II) ion with ciprofloxacin. Croat Chem Acta 75:1-12 